\title{
ПІДГОТОВКА МАЙБУТНІХ ВИХОВАТЕЛІВ ДО ФОРМУВАННЯ ЛОГІКО- МАТЕМАТИЧНИХ ПОНЯТЬ У ДІТЕЙ СТАРШОГО ДОШКІЛЬНОГО ВІКУ
}

Іщенко Л. В. Підготовка майбутніх вихователів до формування логіко-математичних понять у дітей старшого дошкільного віку.

Стаття присвячена ознайомленню майбутніх вихователів з ефективними формами та методами формування логіко-математичних понять у дітей старшого дошкільного віку. Доведено ефективність використання в практичній роботі вихователів дошкільних навчальних закладів нетрадиційних методів навчання математики (проблемні ситуації та завдання, завдання 3 елементами пошуку, задачі-жарти, задачі-загадки, задачі з казковим сюжетом).

Ключові слова: логіко-математичний розвиток, логічні операції, поняття «готовність до школи».

Ищенко Л.В.Подготовка будущих воспитателей к формированию логико-математических понятий у детей старшего дошкольного возраста.

Статья посвящена ознакомлению будущих воспитателей с эффективными формами и методами формирования логико-математических понятий у детей старшего дошкольного возраста. Доказана еффективность использования в практической работе воспитателей детских садов нетрадиционных методов обучения (проблемные ситуации и задания, задания с элементами поиска, задачи-шутки, задачи со сказочным сюжетом).

Ключевые слова: логико-математическое развитие, логические операции, понятие «готовность к школе».

Ischenko L. V. Preparation of future educators to form logical and mathematical concepts of children of the advanced preschool age.

Article is devoted to acquaintance of future tutors with effective forms and methods of formation of logical-mathematical concepts of children of the advanced preschool age. Efficiency of use in practical work of tutors of kindergartens of nonconventional methods of training (problem situations of a task, a task with elements of search, a task joke, a task with a fantastic plot) is proved.

Key words: logik-mathematical development, boolean operations of concept «readiness to school».

У Національній доктрині розвитку освіти України у XXI столітті, Законі України «Про дошкільну освіту» наголошено на важливості розроблення освітніх технологій, спрямованих на розвиток у дитини найбільш продуктивних видів і форм мислення.

Логіко-математичний розвиток дошкільника - один з найважливіших аспектів його підготовки до школи, оскільки передусім сприяє формуванню в майбутнього школяра вміння розв'язувати інтелектуальні і практичні завдання в різних видах діяльності, оперувати моделями розв'язку.

У наукових дослідженнях доведено спроможність дітей старшого дошкільного віку розуміти нескладні за змістом наукові поняття (Л. Виготський, П. Гальперін, С. КабановаМеллер, 3. Калмикова, О. Леонтьєв, Н. Менчинська, С. Рубінштейн, Н. Тализіна, А. Усова), виявлено суттєві зв'язки дійсності, які є доступними дошкільникам у предметно-чуттєвій пізнавальній діяльності (Л. Венгер, О. Запорожець), генезу поняття «число» й особливості усвідомлення дітьми числових абстракцій (М. Вовчик-Блакитна, П. Гальперін, В. Давидов, Г. Костюк).

Науковцями вивчено формування в дошкільників операцій рахунку (О. Грибанова, Г. Леушина, Н. Менчинська, Н. Непомняща), особливостей сприйняття геометричних фігур і форм об'єктів (З. Богуславська, О. Запорожець, Є. Корзакова, Л. Пеньєвська, А. Рузська, В. Сохіна), засвоєння величини предметів і формування просторових уявлень (В. Котирло, Т. Мусейбова), складено низку методичних посібників, які спрямовані на 
розвиток логічного, творчого мислення дітей дошкільного віку в процесі формування математичних понять (Г. Леушина, Л. Метліна, А. Столяр, К. Щербакова та ін.), досліджено методику реалізації індивідуально-диференційованого підходу в процесі формування в дітей дошкільного віку математичних уявлень (Н. Баглаєва, Т. Степанова), створено ефективні методики формування елементарних математичних уявлень у дітей старшого дошкільного віку (А. Бєлошиста, Л. Гайдаржийська, Л. Зайцева, О. Фунтікова).

Метою статті $є$ ознайомлення майбутніх вихователів 3 ефективними формами та методами формування логіко-математичних понять у дітей старшого дошкільного віку.

У сучасних програмах з дошкільної освіти, Базовому компоненті дошкільної освіти серед завдань математичного розвитку i математичної підготовки дітей дошкільного віку зазначається потреба у формуванні не лише певних математичних понять і уявлень, а й логіко-математичних понять.

У Базовій програмі розвитку дитини дошкільного віку «Я у Світі», у якій серед показників життєвої компетентності старшого дошкільника визначено й показники логіко-математичної компетентності. Вони включають володіння дітьми математичними поняттями (кількість, форма, величина, час, простір) та логічними операціями (аналіз, синтез, порівняння, узагальнення, класифікація тощо).

Можливість і доцільність поєднання логічного та математичного аспектів були предметом дослідження багатьох вітчизняних та зарубіжних науковців. Зокрема, як одне 3 основних завдань, що мають розв'язуватися в дошкільному віці, визнано перехід від конкретних емпіричних знань до понять наукового характеру. За основу введення таких понять беруться різні математичні та логічні дії [4].

Н. Баглаєва [5] дає визначення дефініціям «логіко-математичний розвиток» і «логікоматематична компетентність», які покладено в основу змістових ліній Базового компоненту дошкільної освіти та детально висвітлено в коментарі до Базового компоненту дошкільної освіти в Україні [2].

Логіко-математична компетентність старшого дошкільника характеризується цілим комплексом умінь. Зокрема, дитина здійснює серіацію за величиною, масою, об'ємом, розташуванням у просторі, перебігом подій у часі; класифікує геометричні фігури, предмети та їх сукупності за якісними ознаками та чисельністю; вимірює кількість, довжину, ширину, висоту, об'єм, масу, час; здійснює найпростіші усні обчислення, розв'язує арифметичні та логічні задачі; виявляє інтерес до логіко-математичної діяльності; прагне знаходити свої шляхи розв'язання завдань, самостійно виводить нові знання із засвоєного.

Готуючи дітей до школи, педагог не повинен забувати про різні темпи дозрівання кори головного мозку й інші індивідуальні психофізіологічні відмінності. Особливо в роботі 3 п’ятирічними малятами, які не відвідували раніше дитсадок. Отже, не весь програмовий матеріал може бути засвоєний усіма без винятку дітьми.

Цілком доступними для кожної дитини вважаємо такі математичні вміння:

- лічити кількість предметів або елементів певної множини;

- порівнювати множини за кількістю елементів способом утворення пар;

- називати числівники в межах 10 при лічбі у прямому та зворотному порядках;

- оперувати множинами: об'єднувати елементи двох множин, що не перетинаються (підготовка до арифметичної дії додавання), вилучати частину елементів множини і лічити решту (підготовка до арифметичної дії віднімання).

Для успішного формування логіко-математичних понять та ефективного розвитку розумових здібностей дітей старшого дошкільного віку необхідно розробити цілісний комплекс завдань, дидактичних ігор і вправ з формування та розвитку кожного поняття у процесі пізнавальної діяльності дитини з визначенням часу їх проведення і місця в режимі ДНЗ.

Цей комплекс складається з урахуванням складності й обсягу навчального матеріалу, вікових та індивідуальних особливостей дітей старшої групи. Він передбачає 
формувальні, закріплюючі та контрольні заняття, розвивальні ігри з розширення й узагальнення знань, продуктивні і репродуктивні вправи на розвиток предметних i розумових дій, завдання для самостійної та індивідуальної роботи дітей. Відповідно до цього змісту доцільно планувати та розробляти дидактичний матеріал для роботи 3 дітьми.

Робота зі старшими дошкільниками 3 формування логіко-математичних понять передбачає систематичність, цілеспрямованість і має здійснюватися з опорою на ті види діяльності, які найбільше сприяють розумовому розвитку дитини.

Зрозуміло, що головна роль на заняттях відводиться розвитку дітей, тому заняття не замінюються ніяким іншим видом діяльності, навіть грою, особливо у старшому дошкільному віці, оскільки для переходу дитини від одного виду провідної діяльності до іншого необхідне формування певного рівня готовності. Ігрова діяльність на заняттях у старшому дошкільному віці не повинна займати більшу частину заняття навіть у тому випадку, коли ігри добираються на закріплення навчального матеріалу і забезпечують математичну підготовку дитини. Головним засобом організації навчання старших дошкільників $\epsilon$ пізнавальні завдання і вправи з формування, закріплення та розширення знань, а також проблемні завдання, що сприяють розвитку навичок використання отриманих знань у нових практичних умовах.

Окрім того, розроблені спеціальні проблемні ситуації, дидактичні вправи спрямовують увагу дітей на розв'язання різноманітних логіко-математичних завдань та розвивають їх кмітливість. Діти вчаться міркувати, доводити свою думку, обгрунтовувати ii,, робити висновки. Самостійне складання розповідей за картинками надає простору дитячій уяві, сприяє розвитку мови, мислення.

Ефективними у формуванні самостійності дітей є завдання, які мають кілька варіантів розв'язання. Дошкільники мають змогу виявити незалежність та ініціативу у виборі рішень. Так, діти самостійно виконують завдання за словесною інструкцією педагога: «Виклади фігури в ряд, щоб поряд не було однакових за розміром або формою».

Дослідженнями науковців доведено, що для успішного самостійного розв'язання дитиною пізнавального завдання вона повинна повністю засвоїти поняття, правила i принципи, що лежать в основі його розв'язання. Повне засвоєння логіко-математичних понять можливе за умови забезпечення єдності понятійних, образних і практичних дій дошкільника, що досягається за допомогою поетапного введення предметних і наочносхематичних моделей навчання.

Діти засвоюють наочно-схематичні моделі тільки за умови систематичної і різноманітної діяльності з ними. Для організації такої роботи педагог розробляє різні види вправ, пізнавальних завдань, ігор з використанням схематичних моделей навчання. Щоб модель була зрозуміла і доступна для дітей, спочатку вихователь їі створює разом 3 дітьми. При цьому називаються умовно прийняті позначки і символи. Діти вчаться добирати прості позначки, які нескладно зобразити, вихователь, якщо необхідно, знайомить дітей 3 умовними загальноприйнятими позначками і символами.

Робота з наочними засобами здійснюється тільки за умови наявності в дітей базових уявлень про певні логіко-математичні поняття, сформовані 3 опорою на предметну модель. Тому перед переходом дітей до роботи з наочно-схематичними моделями педагог повинен бути впевненим у тому, що дошкільники вповні засвоїли матеріал, процеси дій із предметними моделями. Показниками засвоєння матеріалу $\epsilon$ швидкість виконання завдань, безпомилковість, здатність пояснювати результати, знання алгоритму дії, що виражається в можливості перенесення способів виконання завдань у нові подібні ситуації.

У практичній роботі вихователів та вчителів 3 метою логіко-математичного розвитку дітей 5-6 років доцільно використовувати нетрадиційні методи навчання математики: проблемні ситуації та завдання, завдання з елементами пошуку, задачі-жарти, задачізагадки, задачі з казковим сюжетом. 
Добираючи методи навчання, необхідно враховувати рівень актуального й потенційного розвитку дитини, ступінь складності досліджуваного матеріалу, специфіку використовуваних дидактичних засобів, вікові й індивідуальні особливості дитини, цілі і завдання навчання.

Успіх роботи дитини значною мірою залежить від ऑiі здатності контролювати й оцінювати свої дії. Тож вона має навчитися працювати за вказівкою педагога й спрямовувати свою увагу не лише на результат, а й на сам процес. Цьому сприяють такі завдання, як-от: «Пройди лабіринт за схемою», «Намалюй таку саму фігуру», «Продовж ряд», вправи на кодування тощо.

Серед ефективних засобів логіко-математичного розвитку дітей 5-6 років виокремлюємо художнє слово (віршовані задачі, задачі-розповіді, задачі-жарти), народну педагогіку (казки, загадки, прислів'я), проблемні ситуації та завдання, завдання 3 елементами пошуку, дидактичні ігри і вправи.

Матеріали дослідження $є$ спробою обгрунтувати загальні педагогічні основи логікоматематичного розвитку старших дошкільників. Виникає проблема досконалого вивчення психолого-педагогічних особливостей розвитку математичних здібностей дітей старшого дошкільного віку та першокласників, а також співпраці дошкільного закладу, школи та родини.

\section{Лiтература}

1. Баглаєва Н. I. Сучасні підходи до логіко-математичного розвитку дошкільнят / Н. І. Баглаєва // Дошкільне виховання. - 1999. - № 7. - С. 3-4. 2. Базовий компонент дошкільної освіти в Україні // Дошкільне виховання. - 1999. - № 1. - С. 6-9. 3. Белошистая А. В. Дошкольный возраст : формирование и развитие математических способностей / А. В. Белошистая // Дошкольное воспитание. - 2000. - № 2. - С. 69-79. 4. Зайцева Л. І. Математична компетентність : диференційований підхід / Л. І. Зайцева // Палітра педагога. - 2004. - № 2. С. 16-17. 5. Каданкова Н. Н. Психологические особенности детей при переходе от младшего к старшому дошкольному возрасту. Феномен п'яти лет: дис. ... канд. психол. наук / Н. Н. Каданкова. - М., 2000. - 151 с. 6. Скворцова С. Логіко-математична компетентність дитини : Наступність довкілля і школи / С. Скворцова // Дошкільне виховання. - 2011. - № 5. C. $13-18$.

УДК 378 (082)

O. В. Катеруша,

кандидат пед. наук, доиент,

Криворізький економічний інститут

ДВНЗ «Криворізький національний університет»

\section{КОМПЕТЕНТНІСНИЙ ПІДХІД У ПРОЕКТУВАННІ МЕТИ НАВЧАННЯ ІНОЗЕМНИХ MOB}

Катеруша О. В. Компетентнісний підхід у проектуванні мети навчання іноземних мов.

У статті розкрито шляхи формування комунікативних знань, умінь, навичок і способів комунікативної поведінки, які $€$ метою тактичного й оперативного рівнів компетентнісного підходу.

Ключові слова: компетентнісний підхід, комунікативна поведінка, іноземні мови.

Катеруша О. В. Компетентностный подход в проектировании цели обучения иностранным языкам.

В статье раскрыты пути формирования коммуникативных знаний, умений, навыков и способов коммуникативного поведения, которые составляют цель тактического и оперативного уровней компетентностного подхода.

Ключевые слова: компетентностный подход, коммуникативное поведение, иностранные языки.

Katerusha O. V. Competence approach in the design of purpose of training of language teaching. 